\title{
Kebutuhan AAOIFI Sebagai Standar Akuntansi Keuangan Syariah Dalam Harmonisasi Penyajian Laporan Keuangan
}

\author{
Hani Meilita Purnama Subardi \\ Magister Akuntansi, Univeritas Padjadjaran \\ Bandung \\ hanimeilita@gmail.com
}

\begin{abstract}
ABSTRAK
Dengan pesatnya pertumbuhan lembaga keuangan islam yang terjadi di berbagai negara, masih terdapat keraguan akan perlunya standar akuntansi berbasis syariah yang khusus mengatur entitas keuangan islam seperti yang telah dikeluarkan oleh Accounting and Auditing Organization for Islamic Financial Institution (AAOIFI). Hasil Studi literatur ini menawarkan bukti tentang pengaruh standar akuntansi AAOIFI dalam pelaporan Lembaga Keuangan Islam. Temuan menunjukkan ada kebutuhan dalam menyusun pedoman khusus atau standar untuk Lembaga Keuangan Islam dalam kerangka IFRS dalam skala Internasional. Maka dari itu, perlu adanya harmonisasi dan keselarasan antara standar akuntansi yang telah diterima secara umum dan diterapkan di banyak negara seperti IFRS dengan standar akuntansi khusus lembaga keuangan islam. Tanpa kolaborasi semacam itu, pedoman spesifik yang dimaksudkan untuk LKI tidak akan mungkin diterima secara global.
\end{abstract}

Keywords : Lembaga Keuangan Islam, standar akuntansi, AAOIFI, IFRS

\section{Laju Perkembangan Lembaga Keuangan Islam}

Perkembangan industri keuangan syariah di dunia terlihat begitu pesat. Sistem dan industri keuangan syariah tidak lagi menjadi isu lokal yang sifatnya terbatas diantara negara-negara muslim saja, tetapi juga telah menjadi trend global dimana negara-negara non-muslim sudah mengambil posisi dan inisiatif untuk mengadopsi serta mengembangkan system sekaligus industri keuangan syariah ini. Hal ini terbukti sejak sepuluh tahun terakhir, telah banyak berdiri bank-bank syariah di negara Eropa dan Amerika Serikat, seperti Citibank, HSBC, dan Deutsche Bank yang turut mengembangkan industri perbankan syariah selain menjalankan praktek konvensionalnya (Maali \& Napier, 2006). Bahkan lembagalembaga keuangan dunia seperti World Bank dan International Monetary Fund (IMF) telah pula menyatakan bahwa pengembangan keuangan syariah telah menjadi salah satu program utama mereka.

Dengan adanya laju pertumbuhan ini, lembaga keuangan syariah dituntut untuk memiliki transparansi dan akuntabilitas yang baik dalam menjalankan praktik keuangan dan menyajikan laporan keuangannya. Adanya standar akuntansi syariah diharapkan dapat menyajikan informasi yang relevan dan dapat dipercaya kebenarannya. Standar akuntansi juga digunakan oleh pemakai laporan keuangan seperti investor, kreditor, pemerintah, dan masyarakat umum sebagai acuan untuk memahami dan menganalisis laporan keuangan sehingga memungkinkan mereka untuk mengambil keputusan yang benar. Dengan demikian, standar akuntansi memiliki peranan penting bagi pihak penyusun dan pemakai laporan keuangan sehingga timbul keseragaman atau kesamaan interpretasi atas informasi yang terdapat 
dalam laporan keuangan.

Sejalan dengan kebutuhan standar bagi institusi keuangan Islam, Indonesia sebagai salah satu negara yang memiliki populasi muslim terbesar di dunia dengan laju pertumbuhan yang baik pada sektor industri keuangan syariah, merasa memiliki tanggung jawab moral dalam mengembangkan standar pelaporan keuangan berbasis syariah demi masa depan perekonomian Islam di masa depan. Maka dari itu, Bank Indonesia bersama IAI dan Dewan Pengawas Syariah berupaya dalam mengadopsi standar akuntansi keuangan berbasis Islam sesuai dengan kebutuhan praktik keuangan di Indonesia (Rustiana,2016).

\section{Peran AAOIFI dalam memenuhi kebutuhan Standar Akuntansi Berbasis Syariah}

Agar dapat mengatur dan mengawasi institusi keuangan islam, sangat diperlukan metodologi yang tepat dalam membuat peraturan untuk setiap bentuk dan berbagai jenis institusi keuangan islam sehingga nantinya standar tersebut juga dapat diterima secara umum atau global.

Pada skala Internasional, kebutuhan akan standar akuntansi berbasis syariah telah dirumuskan oleh organisasi nirlaba bernama AAOIFI (Accounting and Auditing Organization for Islamic Financial Institution) yang merupakan organisasi internasional Islam yang menyusun standar dan isu-isu terkait akuntansi, audit, pemerintahan, etika, dan standar syariah Islam untuk lembaga keuangan Islam (IFI). Sebagai organisasi internasional yang independen AAOIFI didukung oleh kelembagaan anggota (200 anggota dari 40 negara) termasuk Bank Central, Lembaga Keuangan Syariah, dan anggota lainnya dari industri perbankan syariah di seluruh dunia. Hingga saat ini AAOIFI telah menerbitkan 26 standar akuntansi (Accounting Standard), 5 standar audit (Auditing Standards), 2 standar kode etik (code of ethic) dan 7 standar tata kelola pemerintahan (governance standards) (AAOIFI,2018).

Standar AAOIFI telah diadopsi oleh bank sentral atau otoritas keuangan disejumlah negara yang menjalankan keuangan islam baik adopsi secara penuh (mandatory) atau sebagai dasar pedoman (basis of guidelines). Dalam pergerakannya, AAOIFI didukung oleh sejumlah bank sentral, otoritas keuangan, lembaga keuangan, perusahaan akuntansi dan audit, dan lembaga hukum lebih dari 45 negara termasuk Indonesia. Adapun tujuan penting didirikannya AAOIFI sebenarnya untuk menyiapkan, menyusun dan mengintepretasikan standar akuntansi dan auditing untuk lembaga keuangan syariah, meninjau dan mengubah standar akuntansi dan auditing untuk lembaga keuangan syariah. Tentu saja dengan tujuan penting tersebut diharapkan institusi keuangan islam yang berkembang di seluruh dunia memiliki acuan yang tepat dalam menyusun laporan keuangan berbasis syariah sehingga nantinya dapat diperbandingkan antara laporan keuangan satu dengan yang lainnya (Kamla,2009).

Pertanyaan besarnya adalah, Bagaimana menerbitkan metodologi standar akuntansi yang dapat mengatur berbagai macam tipe dan pola dari bank islam yang dapat diterima umum atau secara internasional? Faktanya, AAOIFI telah berusaha untuk mengembangkan standar bank islam demi mengatasi masalah perbedaan antara produk IFIs dan konvensional. Namun memang dalam implementasinya, standar ini masih bersifat sukarela dan hanya sebagian negara yang mewajibkan kaidah standar ini. Kenyataannya, sejumlah negara berbeda-beda dalam tingkat pengadopsian standar yang dikeluarkan oleh AAOIFI. Negara Bahrain, Oman, Pakistan, Sudan, dan Suriah menjadikan standar syariah dan standar akuntansi AAOIFI sebagai bagian dari peraturan yang wajib untuk diterapkan (mandatory regulatory).

Islamic Development Bank (IDB) juga mengadopsi secara penuh. Sedangkan Brunei, Dubai International Financial Centre, Mesir, Perancis, Kuwait, Lebanon, Malaysia, Arab Saudi, Afrika Selatan, Uni Emirat Arab dan Inggris serta di Afrika dan Asia Tengah hanya menerapkan standar AAOIFI secara sukarela (voluntary) bagi lembaga keuangan syariah. Di Indonesia sendiri standar syariah dan standar akuntansi AAOIFI dijadikan 
sebagai dasar pedoman dalam penyusunan standar syariah dan standar akuntansi syariah. Sedangkan Malaysia menjadikan standar yang dikeluarkan AAOIFI sebagai panduan dalam praktek keuangannya meski dalam kenyataannya Malaysia masih menggunakan penggunaan IFRS dalam kaidah penyusunan pelaporan keuangan untuk Institusi Keuangan Islam (Mohammed et. al., 2015).

\section{Kendala dalam Penerapan Stamdar AAOIFI}

Saat ini, Lembaga Keuangan Islam atau Islamic Financial Institutions (IFIs) tidak hanya berkompetisi dengan bank konvensional di negara-negara muslim namun industri ini telah berkembang sangat pesat di negara-negara barat seperti Amerika Serikat, United Kingdom dan Australia (Haron and Wan Azmi, 2008). Sayangnya, masih terdapat kendala pada penerapan standar untuk IFIs dikarenakan lembaga keuangan yang ada masih didominasi oleh lembaga konvensional sehingga dalam penyajian laporan keuangannya masih mengikuti sistem konvensional.

Artikel ini selanjutnya akan mengupas lebih dalam terkait kendala yang terjadi dalam penerapan standar AAOIFI berdasarkan Jurnal yang dibuat oleh Mohammed et. al. 2015 dengan judul penelitian The Influence of AAOIFI Accounting Standards in Reporting Islamic Financial Institution in Malaysia. Selanjutnya, akan dibandingkan pula kendala tersebut yang terjadi di berbagai negara termasuk Indonesia.

Setidaknya terdapat 2 hal yang dibutuhkan Institusi Keuangan Islam dalam sistem pelaporannya. Pertama, persyaratan atau aturan berbasis syariah, kedua aturan yang dapat relevan untuk dipraktekkan. Jika dilihat pada praktek pengaplikasian standar, kendala terbesar saat ini yakni, adanya kesulitan dalam tingkat pemahaman para akuntan dan tingkat kepatuhan dari bank islam secara global dikarenakan terdapat perbedaan impelmentasi standar yang diterapkan IFRS, ataupun standar akuntansi lokal pada pelaporan keuangan di bank islam seluruh dunia.

Masalah dari keefektifan pengawas dan badan pengatur menjadi tantangan utama untuk lembaga keuangan islam yang beroperasi di institusi keuangan yang kompleks dan dinamis. Meskipun IFRS dapat menjadi acuan bagi kaidah penyusunan laporan keuangan, namun masih sangat diragukan jika menggunakan standar tersebut dalam lembaga keuangan islam dan menyamakan standarnya dengan bank konvensional. Karena Institusi tersebut dikembangkan dengan tujuan untuk memenuhi prinsip syariah, maka penelitian sebelumnya menyatakan bahwa perlu adanya perbedaan yang jelas antara standar akuntansi syariah dan konvensional. (Vinnicombe, 2010). Ini sangat penting bagi IFIs untuk mendapatkan kepercayaan publik dengan melaporkan laporan keuangan yang sesuai dengan aturan syariah dan juga produkproduk keungan yang sesuai dengan prinsip syariah

Sebenarnya, kehadiran standar dalam AAOIFI tidak pernah dimaksudkan untuk menyaingi IFRS, namun sebagai pelengkap dalam menyusun laporan keuangan IFIs. Pandangan ini menyetujui perkembangan AAOIFI dalam menyusun standar untk IFIs dengan mengadopsi standar dari Bank western konvensional. Dikarenakan standar pada AAOIFI sangat banyak dan mengikuti standar-standar yang telah ada maka IFRS memiliki hak lebih tinggi dalam pelaopran IFIs, dan AAOIFI hanya digunakan sebagai referensi.

Untuk mengaji lebih dalam terkait kendala yang ada dalam proses penerapan standar, terdapat wawancara yang dilakukan oleh Mohammed et.al kepada tujuh orang yang memiliki pengaruh penting terhadap penyajian laporan keuangan berbasis syariah di Malaysia yang semakin memperjelas perkara yang ada. Pertama, beberapa koresponden sepakat bahwa masalah perbandingan antara AAOIFI dan IFRS standar ini telah menjadi hambatan utama dalam pengadopsian AAOIFI di Malaysia. Terlebih banyak negara yang memutuskan untuk menggunakan perangkat standar yang sama yakni IFRS untuk mempermudah dalam penyetaran penerbitan laporan keuangan. Hal 
ini semakin mempersulit pemisahan standar lembaga keuangan islam di Malaysia. Kedua, Jumlah pengungkapan yang dipersyaratkan oleh AAOIFI dalam laporan keuangan juga menjadi penghambat dalam pengadopsian AAOIFI yang menguras waktu dan biaya, sehingga penerapannya masih dipertanyakan.

Penggunaan standar AAOIFI di

Malaysia hanya terbatas sebagai panduan dan pelengkap. Koresponden juga mengatakan bahwa Malaysia dan Bahrain memiliki perbedaan mazhab dari para pakar ekonomi islam terkait interprestasi akad dan produk. Syariah Advisory Council di Malaysia masih sangat liberal dan jauh dari tujuan (maqassid al-Shariah), maka dari itu terdapat banyak bank konvensional yang masih menawarkan produknya kepada IFIs. Malaysian Accounting Standards Board (MASB) menyatakan bahwa tidak ada keharusan dalam pemisahan standar akuntansi untuk lembaga keuangan Islam karena tidak ada perbedaan yang signifikan dalam pencatatan antara produk IFIs dan konvensional.

Meskipun kewajiban dalam penyajian laporan keuangan buat IFIs adalah IFRS beberapa koresponden mengatakan bahwa standar AAOIFI masih diterima dikarenakan semangat islam yang ada dari umat muslim di Malaysia. Banyak hal yang masih harus dibenahi dalam penerapan AAOIFI di Malaysia, seperti infrastruktur, pendidikan tentang keuangan syariah sebelum mengimplementasikannya dan untuk mencapai hal itu diperlukan waktu yang lama serta sumber yang credible.

\section{Penerapan Standar Akuntansi Syariah di Indonesia}

Perbedaan pendapat tentang bagaimana untuk memperhitungkan transaksi keuangan akuntansi syariah dan pro kontra standarisasi akuntansi syariah yang muncul akibat konvergensi IFRS merupakan sebuah pembelajaran yang penting dalam pengembangan teori akuntansi syariah yang ada saat ini, terutama di Indonesia. Penyatuan dua prinsip yang berbeda antara standar IFRS dan standar yang dibuat oleh AAOIFI tidak akan menyelesaikan masalah di antara kedua teori akuntansi yang berbeda, maka penyesuaian merupakan salah satu strategi untuk menghadapi perbedaan yang ada. Apabila memang sebuah konsep tidak sesuai dengan IFRS sebaiknya jangan dipaksakan untuk digunakan dan apabila dapat digunakan maka pergunakanlah sebaik mungkin. Tantangan untuk para pembuat standar dan pihak yang berkepentingan adalah untuk meningkatkan komparabilitas lintas batas transaksi keuangan syariah, sementara memperhatikan sensitivitas agama dan bukannya memaksakan standar IFRS yang ada untuk digunakan. Meskipun IFRS merupakan standar yang diterima secara internasional, namun adanya kenyataan bahwa terdapat beberapa prinsip IFRS yang tak dapat diaplikasikan dengan interpretasi syariah, serta bahwa kerangka kerja pelaporan keuangan yang terpisah untuk transaksi keuangan syariah dibenarkan untuk dilakukan.

Isu-isu penting yang telah dibahas di atas menunjukkan bahwa prinsip akuntansi syariah dan akuntansi konvensional berbeda. IFRS yang merupakan standar internasional yang mengacu pada akuntansi konvensional nampaknya ada beberapa bagian yang tidak cocok dengan prinsip akuntansi syariah ini. Konvergensi IFRS terhadap standar akuntansi syariah yang dilakukan di Indonesia tidak akan bisa sempurna seratus persen. AAOIFI dalam hal ini telah memformulasikan alternatif standar akuntansi syariah ini berkaitan dengan konvergensi IFRS ini. AAOIFI dalam formulasinya menyatakan bahwa ketika IFRS tidak bisa diadopsi secara keseluruhan oleh IFI, ketika IASB tidak memiliki IFRS untuk menutupi praktek perbankan syariah dan praktek keuangan syariah, dan ketika IFRS tidak dapat diadopsi maka AAOIFI tidak akan mengembangkan standar atau berkembang dan mengadopsi IFRS. Kesenjangan dan perbedaan akan selalu ada dan akan terus ada di antara kedua standar, karena kesenjangan dan perbedaan adalah hasil alami dari struktural tujuan yang berbeda dari IASB dan AAOIFI. IAI sendiri dalam hal ini juga mengacu pada AAOIFI dalam menanggapi permasalahan konvergensi IFRS ini. 


\section{Kesimpulan}

Dengan laju pertumbuhan Institusi Keuangan Islam di dunia yang begitu pesat, dibutuhkan standar baku yang tepat dalam penyajian laporan keuangan untuk mengatasi perbedaan dalam penyusunan masing-masing negara. Peran AAOIFI dalam hal ini sudah sangat berkontribusi dalam hal perumusan standar, meskipun dalam praktek pengaplikasiannya banyak ditemukan kendala, terlebih standar yang banyak digunakan oleh negara adalah IFRS dan ini menjadi tidak mudah bagi negara untuk mengadopsi standar AAOIFI dalam waktu yang singkat. Berbagai negara yang memiliki institusi keuangan islam dan AAOIFI masih memiliki tugas penting yang harus diselesaikan, yakni bagaimana membuat kebijakan dan standar keuangan berbasis syariah yang tepat agar dapat diterima secara global.

\section{REFERENSI}

[1] AAOIFI. (2018). Accounting, Auditing and Governance Standards for Islamic Financial Institution, Accounting and Auditing Organisation for Islamic Financial Institution. Bahrain.

[2] Kamla, G. (2009). Islam, Nature and Accounting: Islamic Principles and the notion of accounting for the environment. Accounting Forum.
[3] Mohammed, N. F., Fahmi, F. M., \& Ahmad, A. E. (2015). The Influence of AAOIFI Accounting Standards in Reporting Islamic Financial Institution in Malaysia. ScienceDirect.

[4] Rustiana, S. H. (2016). The Development Of Syariah Accounting In Indonesia. Research Gate.

[5] Sarea, A. M., \& Hanefah, M. M. (2013). The Need of Accounting Standards for Islamic Financial Institution. International Management Review.

[6] Vinnicombe. (2010). AAOIFI Reporting Standards Measuring Compliance. Advance in Accounting.

[7] Haron, S., \& Azmi, W. (2008). Determinants of Islamic and Conventional Deposits in The Malaysian Banking System. Managerial Finance.

[8] Jazil, T., \& Syahruddin. (2013). "The Performance Measures of Selected Malaysian and Indonesian": Islamic Banks Based on The Maqasid al-Shari'ah Approach. Loughbhorough University.

[9] Maali, B., \& Napier, C. (2006). Social Reporting. ABACUS: Islamic Banks. 